\title{
Composition and Antioxidant Activity, Supercritical Carbon Dioxide Extraction Extracts, and Residue after Extraction of Biologically Active Compounds from Freeze-Dried Tomato Matrix
}

\author{
Dalia Urbonavičienè ${ }^{1, *}$, Česlovas Bobinas ${ }^{1}$, Ramunė Bobinaitė ${ }^{1}$ (D), Lina Raudonè ${ }^{2}$ (D), Sonata Trumbeckaitė ${ }^{2,3}$, \\ Jonas Viškelis ${ }^{1}$ and Pranas Viškelis ${ }^{1}$ (D)
}

\section{check for} updates

Citation: Urbonavičienè, D.; Bobinas, Č.; Bobinaitè, R.; Raudonè, L.; Trumbeckaitè, S.; Viškelis, J.; Viškelis, P. Composition and Antioxidant Activity, Supercritical Carbon Dioxide Extraction Extracts, and Residue after Extraction of Biologically Active Compounds from Freeze-Dried Tomato Matrix. Processes 2021, 9, 467. https://doi.org/10.3390/pr9030467

Academic Editor: Francesca Blasi

Received: 1 February 2021

Accepted: 3 March 2021

Published: 5 March 2021

Publisher's Note: MDPI stays neutral with regard to jurisdictional claims in published maps and institutional affiliations.

Copyright: (c) 2021 by the authors. Licensee MDPI, Basel, Switzerland. This article is an open access article distributed under the terms and conditions of the Creative Commons Attribution (CC BY) license (https:// creativecommons.org/licenses/by/ $4.0 /)$.
1 Lithuanian Research Centre for Agriculture and Forestry, Institute of Horticulture, 54333 Babtai, Lithuania; ceslovas.bobinas@lammc.lt (Č.B.); ramune.bobinaite@gmail.com (R.B.); jonas.viskelis@lammc.lt (J.V.); pranas.viskelis@lammc.lt (P.V.)

2 Department of Pharmacognosy, Lithuanian University of Health Sciences, 50162 Kaunas, Lithuania; lina.raudone@lsmuni.lt (L.R.); sonata.trumbeckaite@lsmuni.lt (S.T.)

3 Neuroscience Institute, Lithuanian University of Health Sciences, 50161 Kaunas, Lithuania

* Correspondence: d.urbonav@gmail.com; Tel.: +37-068-308-157

Abstract: Supercritical carbon dioxide extraction $\left(\mathrm{SCE}-\mathrm{CO}_{2}\right)$ is an attractive, green technology that is used for the recovery of biologically active compounds from plant material. The antioxidant potential of lipophilic fractions (extract obtained with SCE- $\mathrm{CO}_{2}$ ) and hydrophilic fractions (extracts obtained from the residue after extraction) obtained from a matrix of freeze-dried tomatoes (cvs. "Admiro" F1, "Jurgiai", "Vilina", "Pirmutis", and "Skariai") was assessed via different antioxidant activity methods. The total amount of polyphenols, carotenoids, and carotenoid isomers before and after $\mathrm{SCE}-\mathrm{CO}_{2}$ extraction was also determined. To investigate the effect of the SCE- $\mathrm{CO}_{2}$ extract on the viability of cancer cells, rat glioblastoma $\mathrm{C} 6$ cells were chosen. The $\mathrm{SCE}-\mathrm{CO}_{2}$ yielded an average of $800 \mathrm{mg}$ of lipophilic fraction per $100 \mathrm{~g}$ of freeze-dried tomatoes. The ABTS ${ }^{\bullet+}$ scavenging activity of the extract was $251 \pm 3.4 \mu \mathrm{mol} \mathrm{TE} / \mathrm{g}$. After SCE- $\mathrm{CO}_{2}$ extraction, the DPPH$\bullet-R S A$ of the freeze-dried tomato matrix was 7 to $12 \%$ higher. There was a strong positive correlation $(R=0.84)$ between the total polyphenolics content and the DPPH•-RSA of the tomato samples. The SCE-CO ${ }_{2}$ increased the radical scavenging activity of the extraction residue, indicating that a considerable fraction of the hydrophilic compounds with particular antioxidant capacity remain unextracted from the tomato matrix. Our results reveal the cytotoxic effect of lycopene extract rich in cis-isomers $(62 \%$ cis-isomers of the total lycopene content) on rat glioblastoma C6 cells. The viability of the glioblastoma C6 cells significantly decreased $(-42 \%)$ at a total lycopene concentration of $2.4 \mu \mathrm{M}$ after $24 \mathrm{~h}$ of incubation.

Keywords: lycopene; tomato; supercritical fluid extracts; antioxidant activity; cytotoxic effect

\section{Introduction}

The development of health-promoting food products is a key research priority [1]. Vegetables are highly recommended for a healthy diet due to their high contents of bioactive components, including antioxidants [2,3]. Plants are an important source of bioactive compounds and functional ingredients with beneficial health properties. In order to assess the efficacy of plants as functional foods and/or sources of ingredients for food supplements, it is important to describe their quality and physicochemical properties, to determine the composition and quantity of the present bioactive compounds and evaluate their bioactivity [4].

Recently, natural carotenoids and phenolic substances have attracted great attention from the scientific community as potential agents for the prevention of oxidative-stressrelated diseases [5]. A significant link between the regular intake of phytochemical-rich 
foods (e.g., foods rich in carotenoids, phenolic compounds) and the prevention of certain degenerative diseases (cancer, arthritis, diabetes, cardiovascular diseases, etc.), as well as the enhancement of the immune function, have been demonstrated in many studies [6]. Carotenoids and phenolic compounds contribute to the nutritional value of tomatoes and affect their quality attributes (aroma, taste, texture, and appearance) [7-9]. Diets rich in natural carotenoids (lycopene, $\beta$-carotene, et al.) have been associated with many health benefits. Carotenoids are a class of naturally occurring fat-soluble pigments responsible for the characteristic (yellow, orange, red) colors of numerous fruits and vegetables. These natural pigments play a very important role in human health and disease (cancer, cardiovascular diseases, macular degeneration) prevention [10,11]. Lycopene is the major carotenoid occurring in ripe tomatoes, accounting for up to $90 \%$ of the total carotenoids present. Lycopene is not synthesized in the human body; therefore, it must be acquired from the daily diet [12]. Lycopene ( $\psi, \psi$-carotene) is a symmetrical tetraterpene with eight isoprene units. Lycopene has a molecular formula of $\mathrm{C}_{40} \mathrm{H}_{56}$, which has been attributed to its chemical structure, containing 13 double bonds, 11 of which are conjugated. Although 71 kinds of lycopene cis-isomers are theoretically possible because of the stereo-hindrance of double bonds $[13,14]$, lycopene in plant sources-for example, in tomatoes and other fruits-exists predominantly in an all-trans-isomers form. The molecular structure of a nutrient (for example, cis- or trans-conformation, the number of carotenoids) determines its biological role and activity [15]. For instance, in human plasma, cis-isomers of lycopene make up at least $60 \%$ of the total lycopene [16,17]. The predominant lycopene cis-isomers (5-cis; 7-cis; 9-cis; 13-cis; 15-cis) in tomatoes and tomato products were revealed in our previous works $[18,19]$. According to the literature, lycopene exhibits the highest antioxidant activity compared with other carotenoids [20,21].

It has been widely accepted that no single antioxidant alone can lead to health benefits. Rather, the combination and possible synergistic effects of various present antioxidants are necessary. There is an opinion that carotenoids sometimes interact synergistically with other natural antioxidants. Carotenoid mixtures show higher bioactivity than single compounds. The synergistic interaction of lycopene and $\beta$-carotene was reported previously [15,22]. Milde and co-w [23] tested the effect of a combination of rutin and carotenoids (lutein and lycopene) on the oxidation of human low-density lipoproteins (LDL). Both combinations were shown to facilitate synergistic (supra-additive) protection of LDL towards oxidation. The authors concluded that this is most likely due to the different allocation of the antioxidants in the LDL particles and the different mechanisms of antioxidant action [23]. Besides carotenoids, phenolic compounds also contribute to the beneficial health effects of tomatoes and tomato products. Phenolic compounds such as flavonoids are the most important compounds in tomato fruits and have strong antioxidant activity [24]. The antioxidant activity of phenolic compounds is mainly due to their capacity to block the generation of reactive oxygen and nitrogen species (ROS and RNS, respectively) [25].

Nowadays, the interest in concentrated bioactive food constituents with antioxidant potential is increasing. Thus, it is very important to preserve as many biologically valuable compounds as possible from the primary product. It is worth emphasizing that freezedrying is commonly used in laboratories to stabilize and store highly sensitive biological materials since, in the freeze-dried materials, no enzymatic reactions can occur [26]. It is also important to note that the freeze-dried tomatoes could be utilized as a replacement for fresh fruits in various recipes. Freeze-dried plant products (seasoning, various snack foods, etc.) are becoming increasingly available to the general population in health food stores and supermarkets. Rizzo and colleagues [27] reported that the pre-treatment of cherry tomatoes with a dipping solution preserves nutritional components (polyphenols, vitamin C) in the partially dried product.

It is known that the freeze-drying process preserves the composition of the plant material [28]. Therefore, in this study, in order to protect lycopene and other carotenoids as well as polyphenolic compounds from oxidation, tomato fruits of different varieties were lyophilized before the extraction process. 
Lycopene is of high commercial value due to its application as a natural pigment and bioactive compound with functional properties. It can be used in nutraceuticals, cosmeceuticals and pharmaceuticals, and as an ingredient in different foods and beverages. The global market for carotenoids is expected to reach USD 2 billion by 2022 [29]. Consequently, oleoresins from tomatoes have good potential for industrial applications.

Supercritical carbon dioxide extraction $\left(\mathrm{SCE}-\mathrm{CO}_{2}\right)$ is an alternative process to conventional organic solvent extraction. $\mathrm{SCE}-\mathrm{CO}_{2}$ fits all the requirements for the green, sustainable recovery of functional components from plant materials [19]. In this study, the antioxidant potential of tomato lipophilic fractions, obtained by supercritical carbon dioxide extraction $\left(\mathrm{SCE}-\mathrm{CO}_{2}\right)$, as well as remaining solid extraction residues, were evaluated. The study aimed to isolate lycopene-rich extracts from different tomato varieties using an environmentally friendly extraction process.

The aim of the work was to assess the antioxidant activity of freeze-dried tomatoes of different varieties. To investigate the effect of the extracts on the viability of cancer cells, rat glioblastoma C6 cells were chosen. The evaluation of the antioxidant activity of hydrophilic and lipophilic fractions was conducted via supercritical carbon dioxide extraction (SCE$\mathrm{CO}_{2}$ ) and the antioxidant activity of the remaining solid extraction residues was assessed. This approach could be regarded as a sustainable alternative to obtaining value-added ingredients from tomatoes for use in foods, nutraceuticals, and pharmaceuticals.

To the best of our knowledge, this is the first study to compare the antioxidant capacity of freeze-dried tomato matrix lipophilic fractions extracted with using SCE- $\mathrm{CO}_{2}$, and the remaining solid residue indicated that these fractions could be used as a source of antioxidants. The obtained extracts could play a very important role in human health through foods, cosmetics, nutraceuticals, and the pharmaceuticals industry.

\section{Materials and Methods}

\subsection{Chemicals, Solvents, and Gasses}

Ethanol (96.6\%) was obtained from MVGroup Production (Kaunas, Lithuania). FolinCiocalteu phenol reagent ( $2 \mathrm{M}$, with respect to acid), gallic acid (3,4,5-trihydroxybenzoic acid, 99\%), 2,2-diphenyl-1-picrylhydrazyl hydrate free radical (DPPH', 95\%), 2,2'-azino-bis(3ethylbenzthiazoline-6-sulphonic acid) (ABTS ${ }^{\bullet+}$ ), 6-hydroxy-2,5,7,8-tetramethylchroman-2carboxylic acid (Trolox, $\geq 97 \%$ ), $\mathrm{Na}_{2} \mathrm{CO}_{3}$, were purchased from Sigma-Aldrich (Steinheim, Germany). The 6-hydroxy-2,5,7,8-tetramethylchroman-2-carboxylic acid (Trolox, $\geq 97 \%$ ) and $\beta$-carotene were obtained from Sigma-Aldrich (Steinheim, Germany).

Carbon dioxide gases (99.9\%) were obtained from Gaschema (Jonava region, Lithuania). Chromatographic analysis was performed using LC-grade solvents.

\subsection{Samples and Experiment}

The experiments were performed in 2020 at the Laboratory of Biochemistry and Technology of the Institute of Horticulture, Lithuanian Research Centre for Agriculture and Forestry. Healthy, ripe, red tomato cvs. "Admiro" F1, "Jurgiai", "Vilina", "Pirmutis", and "Skariai" were visually selected and harvested. Tomatoes were lyophilized using a freeze-dryer FD8512S (ilShin ${ }^{\circledR}$ Europe, Ede, The Netherlands). All samples were ground to powder (particle size $<0.20 \mathrm{~mm}$ ) using a knife mill GM200 (Retsch, Düsseldorf, Germany). The freeze-dried tomato powders were weighed immediately after collection and refrigerated at $-20{ }^{\circ} \mathrm{C}$ prior to the extraction with SCE- $\mathrm{CO}_{2}$.

\subsubsection{Supercritical $\mathrm{CO}_{2}$ Extraction}

The supercritical $\mathrm{CO}_{2}$ extraction was performed on a supercritical fluid extractor, SFT-150 (Supercritical Fluid Technologies, Newark, DE, USA). The stainless-steel extraction vessel had a total internal volume of $500 \mathrm{~mL}$. For each extraction, $30 \mathrm{~g}$ of different ground tomato varieties of the lyophilized tomato matrix was loaded into the extraction vessel. A flow chart diagram of the instrument used is presented elsewhere [18]. To avoid system clogging, the sample was placed between two layers of cotton wool. The volume of $\mathrm{CO}_{2}$ 
consumed was measured using a ball float rotameter and a digital mass flow meter in standard liters per minute $(3 \mathrm{SL} / \mathrm{min})$ at a standard state $\left(\mathrm{P}_{\mathrm{CO} 2}=100 \mathrm{kPa}, \mathrm{T}_{\mathrm{CO}_{2}}=20^{\circ} \mathrm{C}\right.$, $\left.\rho_{\mathrm{CO}_{2}}=0.0018 \mathrm{~g} / \mathrm{mL}\right)$. The extraction parameters were set at a temperature of $73.9{ }^{\circ} \mathrm{C}$, pressure of $43.7 \mathrm{MPa}$, and time of $155 \mathrm{~min}$, according to our previous study [18], to achieve the highest yield of the lipophilic fraction (oleoresin) with cis-lycopene isomers from different tomato varieties. The samples were collected in an amber flask and cooled in an ice bath. Collected extracts were kept at a temperature of $-22{ }^{\circ} \mathrm{C}$ before analysis.

\subsubsection{Carotenoid Extraction}

The total lycopene and $\beta$-carotene contents were determined according to our previous studies [18,30], with slight modifications. The different varieties of freeze-dried tomato samples $(1.0 \mathrm{~g})$ were extracted with a $40-\mathrm{mL}$ mixture of acetone and n-hexane $(1: 3, v / v)$ for $15 \mathrm{~min}$. The whole procedure was repeated three times. The extracts were combined. The total lycopene and $\beta$-carotene contents (considered as $100 \%$ yield) were analyzed using the HPLC method. The total carotenoid content was expressed as $\mathrm{mg} \beta$-carotene equivalents in $100 \mathrm{~g}$ extract. To minimize the interference from other carotenoids, the concentration of lycopene was calculated at $503 \mathrm{~nm}$.

The recovery of total lipophilic fraction from tomato freeze-dried powder was obtained by Soxhlet automated extraction (Behr Labor-Technik, Düsseldorf, Germany), with the mixture of chloroform and hexane $(1: 1, v / v)$, considered as maximum extraction yield $(100 \%)$, which was later compared with the results obtained using $\mathrm{SC}-\mathrm{CO}_{2}$ extraction.

2.2.3. Qualitative and Quantitative Analysis of Lycopene Isomers and $\beta$-carotene Using High-Performance Liquid Chromatography

Lycopene, its isomers (cis- and trans-), and $\beta$-carotene content in freeze-dried tomato powder and lipophilic extracts obtained using $\mathrm{SCE}-\mathrm{CO}_{2}$ from different tomato varieties were determined via high-performance liquid chromatography (HPLC) with a slight modification (Urbonaviciene et al., 2018). Briefly, $0.05 \mathrm{~g}$ of the sample was dissolved in $30 \mathrm{~mL}$ of hexane. The content of carotenoids (lycopene, its isomers (cis- and trans-), and $\beta$-carotene) was monitored using a diode-array detector (DAD, 2998, Water Corporation, Milford, MA, USA). Analytical detection was conducted from 200 to $600 \mathrm{~nm}$. Lycopene and its isomers were detected at $473 \mathrm{~nm}$ and $\beta$-carotene at $450 \mathrm{~nm}$. Chromatographic separations were performed on a RP-C30 column $(5 \mu \mathrm{m}, 250 \times 4.0 \mathrm{~mm}, \mathrm{YMC}$ Europe, Dinslaken, Germany) connected to a C30 guard column $(5 \mu \mathrm{m}, 10 \times 4.0 \mathrm{~mm}$, YMC Europe, Dinslaken, Germany) using a flow rate of $0.7 \mathrm{~mL} / \mathrm{min}$. The temperature of the column was $25{ }^{\circ} \mathrm{C}$. The mobile phase used in the study consisted of methyl tert-butyl ether (solvent A) and methanol (solvent B). Samples were injected at $60 \%$ B (held $5 \mathrm{~min}$ ), and the gradient then changed to $17 \% \mathrm{~B}$ in $50 \mathrm{~min}$. Then, the gradient changed to $0 \% \mathrm{~B}$ in $5 \mathrm{~min}$ (held $10 \mathrm{~min}$ ) and to $60 \% \mathrm{~B}$ in $5 \mathrm{~min}$ (held $10 \mathrm{~min}$ ). All the samples were filtered through a 0.45-mm polyvinylidene fluoride (PVDF) syringe filter (Millipore, Burlington, UT, USA) before injection. To quantify lycopene in the extract samples, a calibration curve was generated using an authentic all-trans-lycopene and all-trans- $\beta$-carotene standard. The levels of cis-lycopene isomers are given in all-trans-lycopene equivalents. The obtained data were processed with the Waters Empower software (Waters Corporation, Milford, MA, USA).

\subsubsection{Analysis of Total Polyphenolic Compounds}

The total polyphenol content in the extracts was determined according to the FolinCiocalteu method, using gallic acid (GA) as the standard, according to the method of Bobinaite et al. [31]. Three $g$ of freeze-dried tomato powder and dried extracts (after SCE$\mathrm{CO}_{2}$ ) were extracted with $50 \mathrm{~mL}$ of aqueous ethanol (70\%). Extractions were carried out in an ultrasound bath for 20 min and then filtered using Whatman paper. The reagent was prepared by diluting a stock solution with ultra-pure distilled water $(1 / 10, v / v)$. Samples $(1.0 \mathrm{~mL}$, three replicates) were introduced into test cuvettes followed by $5.0 \mathrm{~mL}$ of FolinCiocalteu's phenol reagent and $4.0 \mathrm{~mL}$ of $\mathrm{Na}_{2} \mathrm{CO}_{3}(7.5 \%)$. The system was then placed 
at ambient temperature for $1 \mathrm{~h}$. The absorbance of all samples was measured at $765 \mathrm{~nm}$ using a Cintra 202 (GBC Scientific Equipment, Knox, Australia) spectrophotometer. The total concentration of phenolic compounds was determined from the calibration curve and expressed in mg of gallic acid equivalents in one gram of dry sample.

\subsubsection{Assay for Hydrophilic and Lipophilic Antioxidant Activity}

The antioxidant activity of hydrophilic and lipophilic fractions was measured by the TEAC (Trolox equivalent antioxidant capacity) assay as described by Re et al. [32], using the $\mathrm{ABTS}^{\bullet+}$ discoloration method. The fractions were sequentially extracted from $0.1 \mathrm{~g}$ of each sample (three independent replicates from the same batch) with methanol and acetone $(1: 1, v / v)$, respectively, at $5{ }^{\circ} \mathrm{C}$ in an ultrabath for $1 \mathrm{~h}$. The samples were centrifuged at $8800 \times g$ for $7 \mathrm{~min}$. Supernatants were recovered and used for the antioxidant activity assay.

Ten microliters were mixed with $1.0 \mathrm{~mL}$ of $\mathrm{ABTS}^{\bullet+}$ solution and the absorbance decrease was measured at 734 nm in a Cintra 202 (GBC Scientific Equipment, Knox, Australia) spectrophotometer. Methanol and acetone mixtures were used as blanks for hydrophilic and lipophilic extracts, respectively. The antioxidant activity of the samples was calculated, on the basis of the inhibition exerted by standard of Trolox concentrations at $734 \mathrm{~nm}$, inhibition time being fixed at $30 \mathrm{~min}$. Antioxidant activities were expressed as $\mu \mathrm{mol}$ Trolox equivalent (TE)/g oleoresin.

\subsubsection{Analysis of $\mathrm{DPPH}^{\bullet}$ Radical Scavenging Activity (DPPH•-RSA)}

The radical scavenging activity (RSA) of the extracts against stable $\mathrm{DPPH}^{\bullet}$ was determined using the slightly modified spectrophotometric method of Brand-Williams et al. [33]. $\mathrm{DPPH}^{\bullet}$ ethanoic solution $\left(2 \mathrm{~mL}, 6 \times 10^{-5} \mathrm{M}\right)$ was mixed with $20 \mu \mathrm{L}$ of prepared extract. The reaction was carried out at ambient temperatures. The decreasing absorbance at $515 \mathrm{~nm}$ due to the scavenging of $\mathrm{DPPH}^{\bullet}$ was measured with a spectrometer, Genesys-10 UV/Vis (Thermo Spectronic, Rochester, NY, USA), for a period of $30 \mathrm{~min}$ to attain the reaction equilibrium. Simultaneously, the absorption of a blank sample containing the same amount of ethanol and $\mathrm{DPPH}^{\bullet}$ solution was measured daily. The measurements were performed in triplicate.

$\mathrm{DPPH}^{\bullet}$ radical scavenging activity of the samples was expressed as Trolox equivalent (TE) antioxidant capacity ( $\mu \mathrm{mol} \mathrm{TE} / \mathrm{g}$ dry weight of sample).

\subsubsection{Cell Culture}

Rat glioblastoma C6 cells (Lines Service GmbH, Eppelhei, Germany) were used for the experiments. Glioblastoma C6 cells were maintained in DMEM $+10 \%$ fetal calf serum + penicillin $(100 \mathrm{U} / \mathrm{mL}) /$ streptomycin $(100 \mu \mathrm{g} / \mathrm{mL})$ and glutamine $(2 \mathrm{mM})$ medium at $37{ }^{\circ} \mathrm{C}$ in a humidified atmosphere containing $5 \%$ of $\mathrm{CO}_{2}$. Every $3-4$ days, the cells were subcultured.

\subsubsection{Measurement of Intracellular Reactive Oxygen Species in a Glioblastoma Culture}

The lycopene extract with $62 \%$ cis-lycopene isomers (to compare with total lycopene isomers) was separated from SC-CO 2 extracted oleoresin ("Admiro F1") and was analyzed in this study. The extract rich in cis-lycopene isomers $(62 \%)$ was separated using the separated chromatography method with slight modifications [34].

Oleoresins $(10 \mathrm{mg})$ were dissolved in $20 \mathrm{~mL}$ of tetrahydrofuran. The lycopene content and isomerization ratio were measured using HPLC, followed by solvent evaporation in a rotary evaporator and the removal of solvent residue under gentle nitrogen flow. The samples were stored at $-80^{\circ} \mathrm{C}$ until further use or analysis.

Lycopene was identified by comparing the retention times with an authentic standard. The quantitation of lycopene was based on an external standard method. The HPLC chromatograms were monitored at $500 \mathrm{~nm}$.

Reactive oxygen species in a rat glioblastoma C3 cell culture were measured fluorometrically (with excitation of $485 \mathrm{~nm}$ and an emission of $530 \mathrm{~nm}$ ) using $2^{\prime}, 7^{\prime}$-dichlorodi- 
hydrofluorescein diacetate ( $\left.\mathrm{DCFH}_{2}-\mathrm{DA}\right)$ dye. $\mathrm{DCFH}_{2}$-DA easily diffuses into the cells and is deacetylated by cell esterases into DCHF. Reactive oxygen species, e.g., cell-originated hydrogen peroxide, oxidize DCFH into a fluorescent compound DCF compound. The intensity of fluorescence is proportional to the generated amount of $\mathrm{H}_{2} \mathrm{O}_{2}$ in the cells. The cell suspension $\left(3 \times 10^{4}\right.$ cells $/ 200 \mu \mathrm{L}$ ), added to 96 -well plates (each with $0.2 \mathrm{~mL}$ of medium) and loaded with $10 \mu \mathrm{mol} / \mathrm{L}$ of DCHF-DA for $30 \mathrm{~min}$ at $37^{\circ} \mathrm{C}$ in a dark place, was treated with different concentrations of lycopene extract $(0.05,0.1,0.6,1.2,3$, and $6 \mu \mathrm{M})$ (dissolved in DMSO) for $0.5-3 \mathrm{~h}$. Then, the lycopene extract (separated from oleoresin) was carefully washed out with PBS buffer and the generation of ROS was measured using a fluorimeter. The data were compared with the control cell group (untreated with lycopene extract). The used DMSO concentrations had no effect on the production of ROS.

\subsubsection{Evaluation of Cell Viability}

Cell viability was measured using a (3-(4,5-dimethylthiazol-2-yl)-2,5-diphenyltetrazolium bromide (MTT) assay. MTT, a yellow tetrazole, is reduced and turns into a colorful (purple) compound, formazan, depending on the redox status of the living cell. Therefore, the color change of MTT is an indicator of enzymatic oxidation reduction reactions, determined by the activities of various dehydrogenases. The amount of generated formazan is directly proportional to the number of viable cells. The activity of dehydrogenases (and cell viability) was evaluated using an MTT test. The glioblastoma cell culture was treated with different concentrations of lycopene extract $(0.025,0.05,0.1,0.2,0.6,1.2$, and $3 \mu \mathrm{M})$ for $24 \mathrm{~h}$. After this period, the medium was removed; cells were loaded with $0.5 \mathrm{mg} / \mathrm{mL}$ solution of MTT and incubated for $1 \mathrm{~h}$. After the incubation, the light absorption was measured at 570-nm wavelength. The reduction of control cells (untreated with lycopene extract) was equated to $100 \%$.

\subsection{Statistical Analysis}

All the experiments were carried out in triplicate. The mean values and standard deviations of the experimental data were calculated using the software SPSS 20 (SPSS Inc., Chicago, IL, USA). One-way analysis of variance (ANOVA) along with the post hoc Tukey's HSD test were employed for statistical analysis. Differences were considered to be significant at $p<0.05$.

\section{Results and Discussion}

Five varieties of freeze-dried tomato powder ("Admiro" F1, "Jurgiai", "Vilina”, "Pirmutis", and "Skariai") produced in Lithuania were analyzed. The biologically active compounds' composition and antioxidant activity in freeze-dried tomato powder, SCE$\mathrm{CO}_{2}$ extracts, and residue after extraction were analyzed. For the purposes of this study, the total concentration of phenolic compounds with Folin-Ciocalteu's method and the in vitro antioxidant activity of the freeze-dried tomato matrix, $\mathrm{SCE}-\mathrm{CO}_{2}$ extracts, and residue after extraction was investigated using a series of determinations, such as $\mathrm{DPPH}^{\bullet}$ and $\mathrm{ABTS}{ }^{\bullet+}$, respectively.

With SCE- $\mathrm{CO}_{2}$, under optimal conditions, almost all of the lipophilic tomato fractions were extracted (79\%), to compare with Soxhlet extraction. The residue obtained after extraction retains biologically active compounds of diverse hydrophilic nature. The antioxidant properties of the SCE- $\mathrm{CO}_{2}$ extracts were evaluated as well as the residues' antioxidant properties after extraction. Moreover, the particle size of the tomato matrix is an important parameter for determination of biologically active components for $\mathrm{SCE}-\mathrm{CO}_{2}$ extraction. Topal and colleagues [35] mentioned that the recovery of carotenoid lycopene from dried tomato peels was higher when it was ground into small-sized particles [35]. This may be due to the fact that reducing the particle size of the tomato matrix increases the recovery of extract. During the extraction, the small-sized particles' surfaces and the volume ratio of the samples increases the contact area between the fluids [35]. For this reason, all tomatoes 
in this study were first lyophilized and then ground to obtain a tomato powder with an average particle size of $<0.20 \mathrm{~mm}$ and containing $<20 \mathrm{~g} / \mathrm{kg}$ moisture.

The total amount of polyphenols found in the Lithuanian freeze-dried tomato matrix varieties was similar and ranged from 378.2 to $406.5 \mathrm{mg} / 100 \mathrm{~g}$ of dry matter (in the respective cvs. Jungiai and Vilina) in extracts obtained directly from tomato powder before SCE- $\mathrm{CO}_{2}$ extraction. The lowest content of polyphenols was found in the tomato hybrid "Admiro F1" (305.5 mg/100 g dry weight). Similar observations were reported by other scientists and in our previous studies. The total phenolic content DPPH ${ }^{\bullet}$ and ABTS ${ }^{\bullet}+$ scavenging capacity values of extracts obtained via the pressurized extraction of solvents with hexane from rowanberry pomace residue were significantly higher compared with SCE- $\mathrm{CO}_{2}$ extracts [36]. Similar research findings have been presented to compare the antioxidant activity of lipophilic and hydrophilic extracts obtained from berry by-products, with significantly lower antioxidant activity in lipophilic extracts [37].

The total polyphenol compounds in the residue after $\mathrm{SCE}-\mathrm{CO}_{2}$ extraction of tomato samples ranged from $374.9 \mathrm{mg} / 100 \mathrm{~g}$ ("Admiro F1") to $507.7 \mathrm{mg} / 100 \mathrm{~g}$ (Pirmutis), i.e., after supercritical extraction, the concentration of polyphenolic compounds in the samples was 16 to $32 \%$ higher. The obtained results show that polyphenolic compounds were concentrated in the extracted material via supercritical extraction, which explains the increase in the amount of polyphenols in the dry mass (Figure 1).

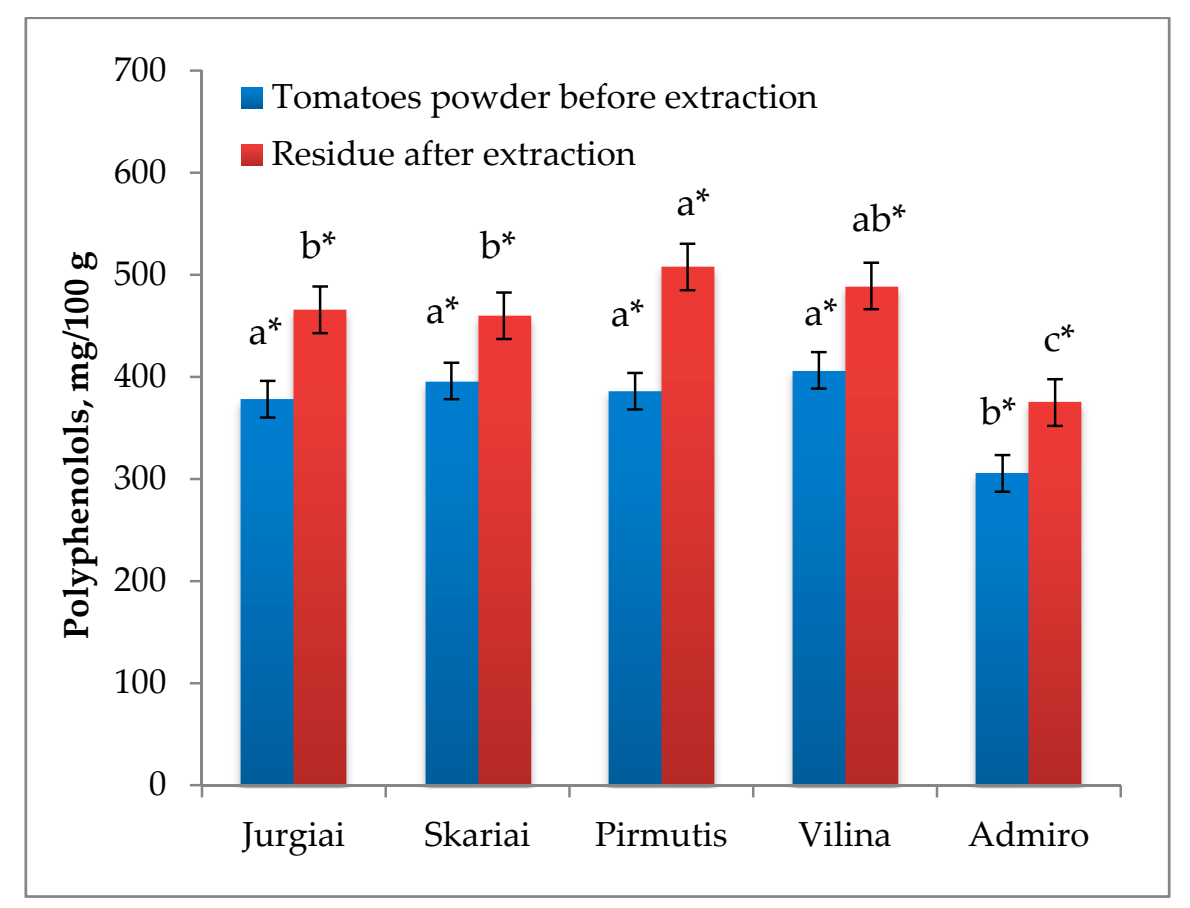

Figure 1. The total amount of polyphenols in tomato powders and residues after $\mathrm{SCE}-\mathrm{CO}_{2}$ extraction. * Different letters above the columns of the same color indicate significant differences between the measured values $(p \leq 0.05)$.

The DPPH $\bullet$-RSA values of the freeze-dried tomato varieties, "Jurgiai", "Skariai", and "Vilina" were similar, on average $-18.1 \mu \mathrm{mol} \mathrm{TE} / \mathrm{g}$ of dry weight. The highest DPPH ${ }^{\bullet}$-RSA was found in tomato variety Pirmutis $(19.7 \mu \mathrm{mol} \mathrm{TE} / \mathrm{g}$ dry weight), and the smallest in the "Admiro F1" (14.9 $\mu \mathrm{mol}$ TE/g dry weight) hybrid (Figure 2). After SCE-CO $\mathrm{CO}_{2}$ extraction, $\mathrm{DPPH}^{\bullet}$ residues values were 7 to $12 \%$ higher. There was a strong positive correlation $(\mathrm{R}=0.84)$ between the total polyphenolics content and DPPH•-RSA of the tomato samples. These findings are in line with previous results reported by Rizzo and co-workers [27], who found a clear correlation between total phenols and antioxidant activity for untreated semi-dry cherry tomatoes $(R=0.98)$ [27]. The $\mathrm{DPPH}^{\bullet}$ radical scavenging activity value from our study is comparable to the values summarized by Szabo et al. [38], who recorded 
$\mathrm{DPPH}^{\bullet}$-RSA ranging between 12 and $25 \mu \mathrm{mol} \mathrm{TE} / \mathrm{g}$ sample in different varieties of tomato waste extracts [38]

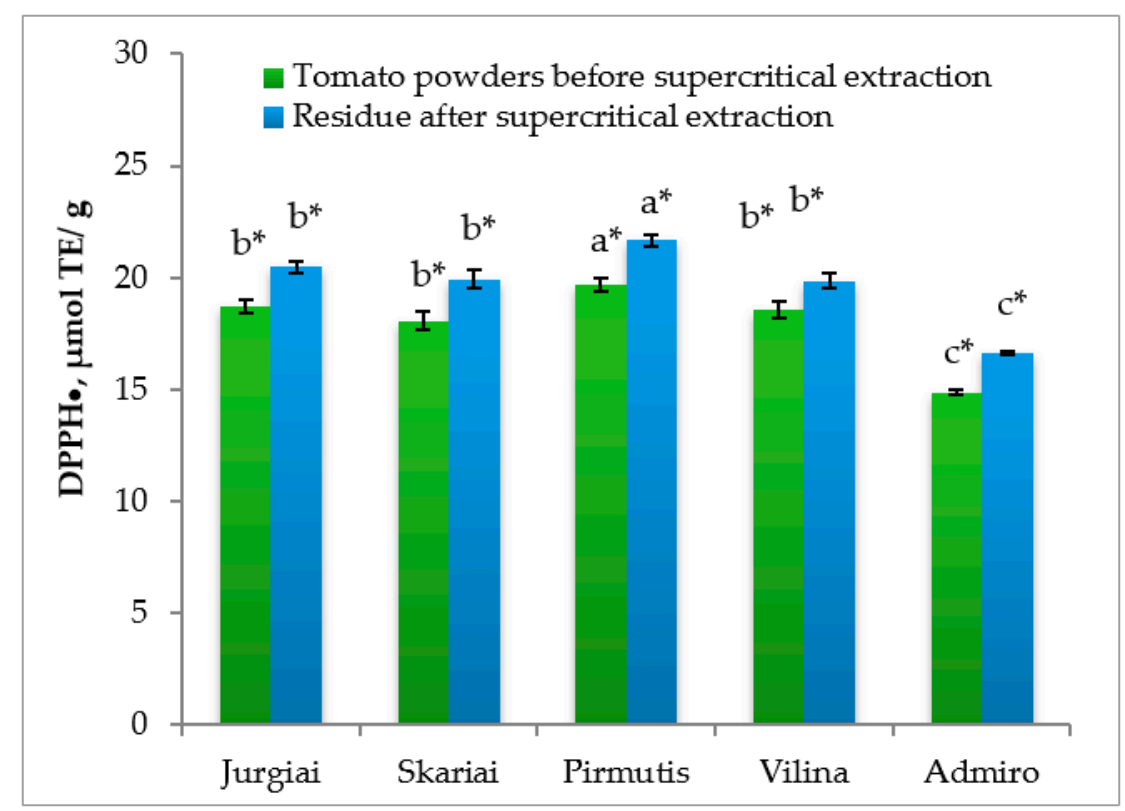

Figure 2. $\mathrm{DPPH}^{\bullet}$ radical binding activity in tomato powders and residues after $\mathrm{SCE}-\mathrm{CO}_{2}$ extraction. * Different letters above the columns of the same color indicate significant differences between the measured values $(p \leq 0.05)$.

The optimal values (at $73{ }^{\circ} \mathrm{C}$ and $53.5 \mathrm{MPa}$ of pressure after 180-min duration) of the process, which were determined in our previous studies, were used in this study for comparative analysis of different tomato varieties. SCE- $\mathrm{CO}_{2}$ extracts from different tomato varieties were used to find the total concentration of carotenoids and their isomers (transand cis-). In particular, the extract of "Vilina" SCE- $\mathrm{CO}_{2}$, a tomato variety with a total concentration of carotenoids of $189 \pm 1.21 \mathrm{mg} / 100 \mathrm{~g}$ of oleoresin, was distinguished. The total concentration of lycopene, $\beta$ carotene, and their isomers in concentrated extracts (oleoresins) of SCE- $\mathrm{CO}_{2}$ is depicted in Figure 3. Genotype differences between cultivars, such as skin thickness, skin/pulp ratio, seed numbers, and dimensions, could significantly affect the amounts of the freeze-dried tomato matrix obtained from fresh tomatoes [38,39].

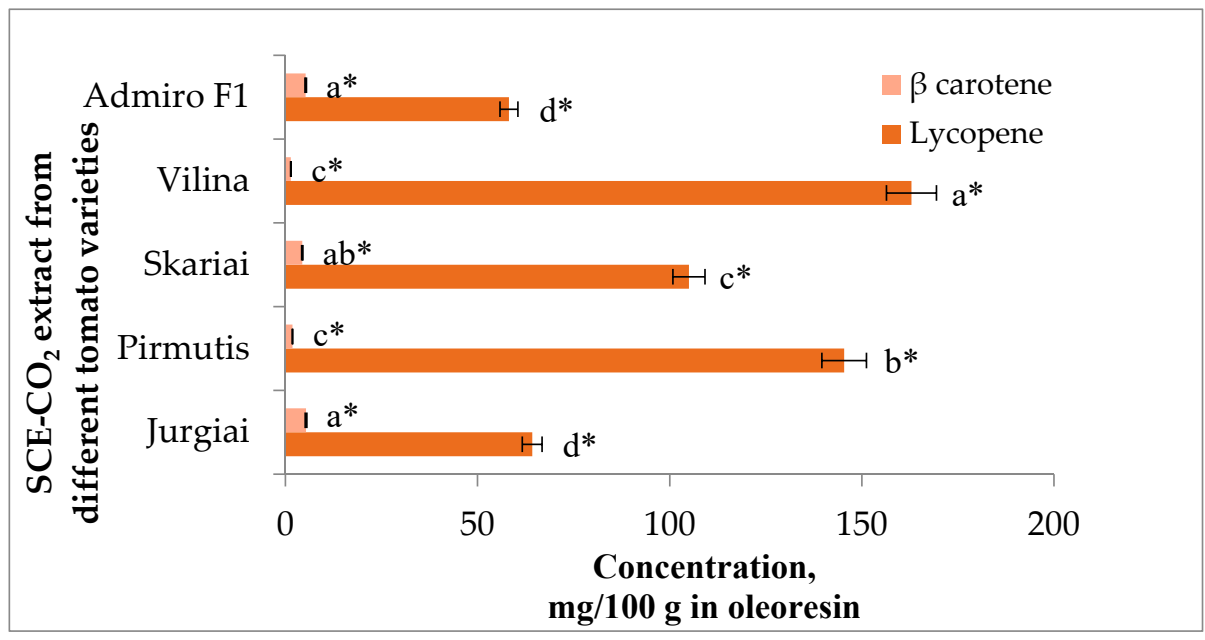

Figure 3. Concentrations of lycopene (trans- and cis-isomers) and $\beta$-carotene contents of different tomato varieties in the oleoresins. ${ }^{*}$ Different letters above the columns of the same color indicate significant differences between the measured values $(p \leq 0.05)$. 
The antioxidant properties of lipophilic extracts were determined and evaluated in $\mathrm{SCE}-\mathrm{CO}_{2}$ extracts from different tomato varieties. The highest antioxidant activity was observed in the oleoresin of tomato varieties ("Skariai" and "Vilina", respectively, 223 and $251 \mu \mathrm{mol} \mathrm{TE} / \mathrm{g}$ ), with the highest concentration of carotenoids (Figure 4). The lowest antioxidant activity was observed in the "Admiro F1" variety (2.6-fold lower than the oleoresin of "Vilina") (Table 1).

Table 1. The antioxidant activity of different lipophilic $\mathrm{SCE}-\mathrm{CO}_{2}$ extracts. ${ }^{*}$ Different letters above the columns of the same color indicate significant differences between the measured values $(p \leq 0.05)$.

\begin{tabular}{|c|c|c|}
\hline Tomato Source & $\begin{array}{l}\text { Carotenoid Content, } \\
\text { mg/100 g of Oleoresin }\end{array}$ & $\begin{array}{l}\text { Antioxidant Activity, } \\
\mu \mathrm{mol} T E / g \text { of Oleoresin }\end{array}$ \\
\hline Jurgiai & $81.8 \pm 3.49^{\mathrm{d} *}$ & $97.1 \pm 4.86^{\mathrm{d} *}$ \\
\hline Skariai & $89.5 \pm 3.83^{d *}$ & $100.7 \pm 5.04^{d *}$ \\
\hline Pirmutis & $140.3 \pm 6.02^{\mathrm{c} *}$ & $167.5 \pm 8.38^{c *}$ \\
\hline Vilina & $189.0 \pm 8.10^{b *}$ & $223.8 \pm 11.19^{b *}$ \\
\hline Admiro F1 & $211.7 \pm 9.04^{\mathrm{a} *}$ & $251.5 \pm 12.58^{a *}$ \\
\hline
\end{tabular}

The quality assessment for lycopene-rich extracts was determined via lycopene, its concentration of isomers, and the proportions of the trans- and cis-lycopene isomer content. The technological parameters of extraction influenced the proportion of different lycopene isomers, at the same time affecting the quality of the extract's composition. The main geometrical isomers of lycopene were 5-cis and 9-cis. The total content of cis-lycopene isomers in the $\mathrm{SCE}-\mathrm{CO}_{2}$ extracts at optimal extraction conditions at $73{ }^{\circ} \mathrm{C}$ and $53.5 \mathrm{MPa}$ of pressure after 180 -min duration of extraction was $62 \%$. The tomato processing pomace of the tomato industry, especially the seeds, generates around 35\% of the oils [40]. The knowledge regarding the extraction of biologically active compounds from the tomato matrix might be helpful for the development and production of cis-isomer-rich carotenoids and polyphenolic compound preparations to manufacture foods or their ingredients with enhanced levels of bio-accessible carotenoids and polyphenols The extraction of biologically active compounds from the tomato matrix may be useful in the development and production of carotenoids rich in cis-isomers, and the compounds from polyphenol group preparations have increased bioavailable carotenoids and polyphenols in manufacturing. The knowledge regarding the properties of isomerized lycopene extract could be useful for developing food supplements, cosmetics, or ingredients for food supplements.

To investigate the effect of lycopene on the viability of cancer cells, rat glioblastoma C6 cells were chosen. Glioblastoma is one of the most aggressive and most common glioma (malignant brain tumors) forms [41]. The exact causes of glioblastoma initiation are not known, but tumor development may be influenced by ionizing radiation, electromagnetic fields, infection, and other undetermined causes. Research on the impact of lycopene isomer extract concentrations $(0.05-2.4 \mu \mathrm{M})$ on glioblastoma cells determined that these concentrations inhibit cell viability by $20-42 \%$ (Figure 4 ). The weakest effect was determined via $0.05 \mu \mathrm{M}$ of lycopene isomers and the greatest effect $(-42 \%)$ was determined via $2.4 \mu \mathrm{M}$ of lycopene isomer extract.

To evaluate the effect of lycopene on the generation of intracellular ROS in glioblastoma cells, the cells were treated with different concentrations of lycopene $(0.05-2.4 \mu \mathrm{M})$. It was determined that lycopene promotes ROS burst in glioblastoma cells by $12,22,34$, and $42 \%$ (Figure 5). 


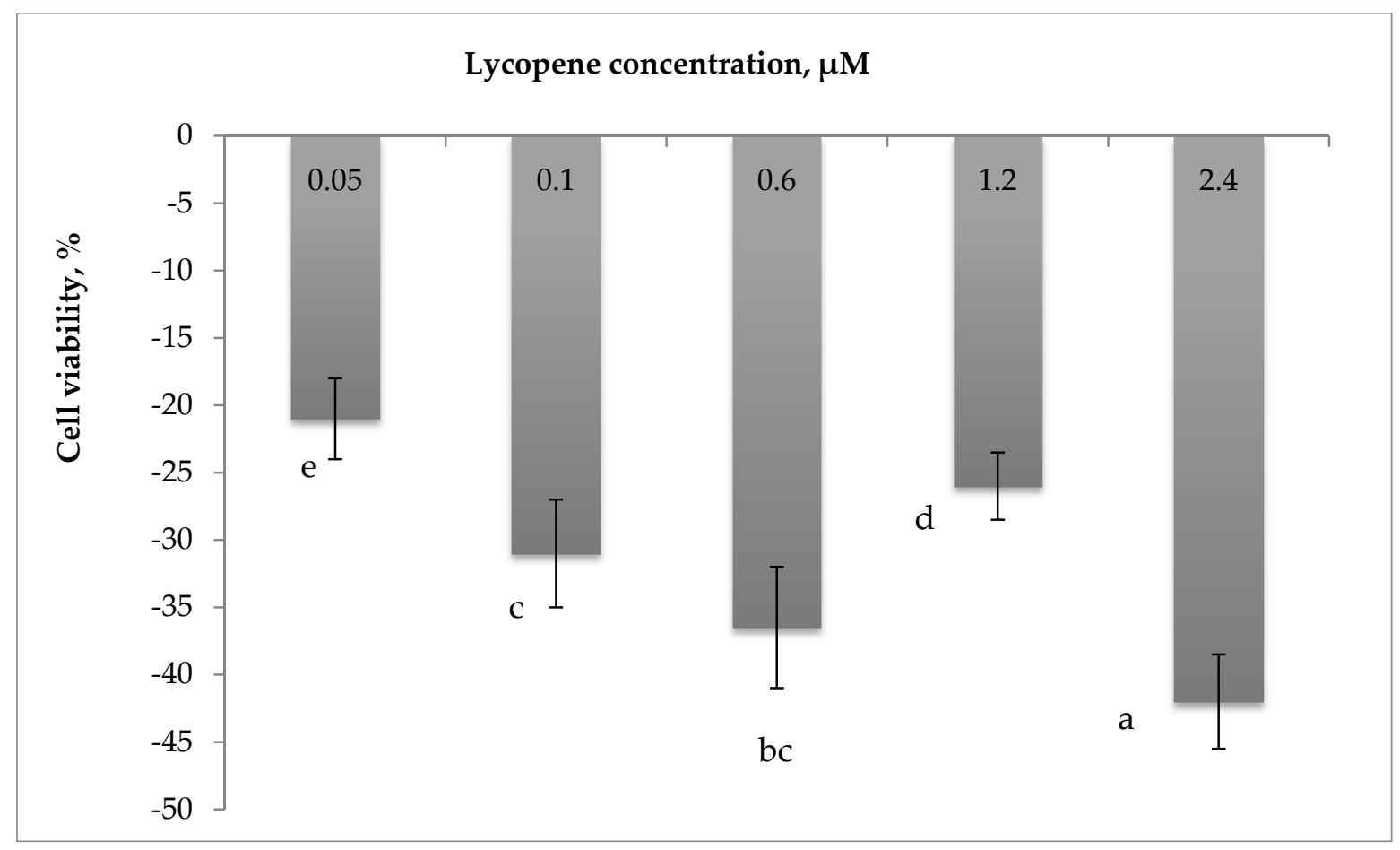

Figure 4. The effects of different concentrations of lycopene on rat glioblastoma cells.

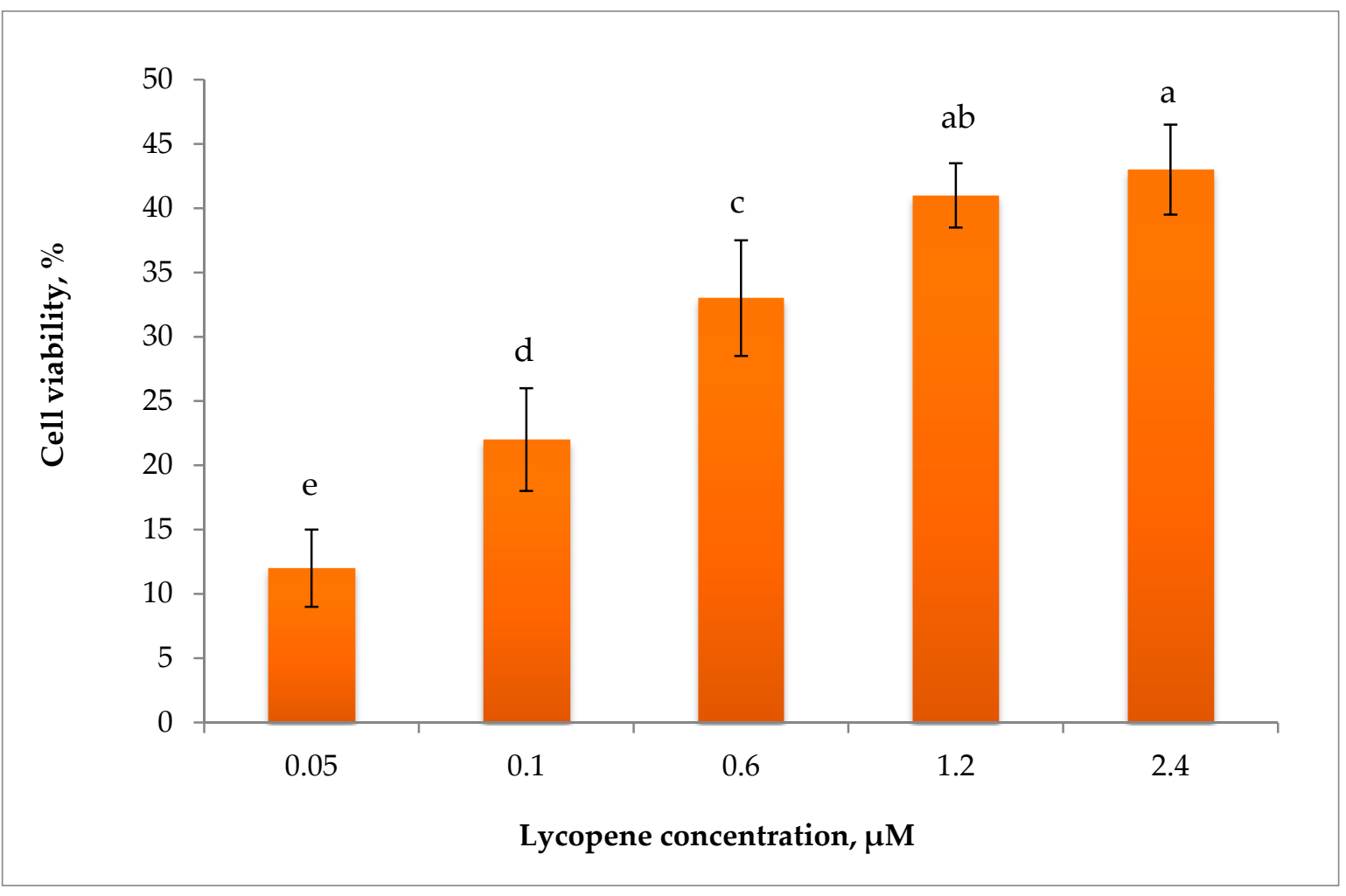

Figure 5. The effect of lycopene on intracellular ROS generation in a rat glioblastoma cell culture.

The effect increases depending on the concentration. The greatest effect $(42 \%)$ was determined using the maximum investigated concentration of 1.2-2.4 $\mu \mathrm{M}$. While it is known that the production of reactive oxygen species involves healthy cell signaling pathways and the alteration in redox status may result in the development of cancer, reactive oxygen 
species may also be used for killing tumor cells [42]. Our results demonstrate that lycopene triggers the generation of ROS in glioblastoma cells and inhibits their viability. However, in a macrophage culture, the generation of ROS triggered by NADPH oxidases is promoted and may be associated with the anti-inflammatory effect of lycopene.

It was suggested that cis-isomers of lycopene have stronger in vitro antioxidant activity to compare with the all-trans form [21]. In most cases, in studies with cells, oxidative damage induced by $\mathrm{H}_{2} \mathrm{O}_{2}$ is measured after preincubation of the cells with carotenoids, but we could not find these experiments with lycopene cis-isomers [43,44]. Zini et al. [45] preincubated human sperm samples with 0.2 or $5 \mu \mathrm{M}$ lycopene before treating them with $\mathrm{H}_{2} \mathrm{O}_{2}(50 \mu \mathrm{M})$ and established protection against DNA SBs (measured with the comet assay) at higher concentrations. In the work of Seo et al. [46], the "Ku70 protein" involved in the repair of a double-strand DNA break and its concentration was decreased in rat pancreatic cells via oxidative stress induced by glucose/glucose oxidase, and it was shown that the decrease was prevented by co-incubation with lycopene. Cell culture studies can provide useful information to evaluate the beneficial effects of carotenoids, particularly their more biologically active forms (for example, cis-lycopene isomers), on human health.

Our results reveal the cytotoxic effect of lycopene-rich cis-isomer (62\%) extract on rat glioblastoma C6 cells. The viability of the glioblastoma C6 cells significantly decreased $(-42 \%)$ at a total lycopene concentration of $2.4 \mu \mathrm{M}$ after $24 \mathrm{~h}$ of incubation.

The extract of lycopene with $62 \%$ cis-isomers decreases the viability of glioblastoma cells. The extract of isomerized lycopene decreases the viability of rat glioblastoma C6 cells by $40 \%$. The extracts of cis-lycopene isomers could be applied as pharmacological agents with anti-proliferative activity.

\section{Conclusions}

In conclusion, the data on the supercritical fluid extraction of lycopene, cis-isomers of lycopene, and $\beta$-carotene could be a basis for the development of technology to isolate high-value biologically active components, thus improving the efficiency of the industrial processing of tomatoes. The use of a freeze-dried tomato matrix of concentrated carotenoid extracts in traditional food products can improve product functionality and increase the efficiency of the industrial processing of tomatoes. Nowadays, there is growing interest in using bioactive food ingredients with potential antioxidant capacity as dyes to replace the synthetic colors currently used in foodstuffs. The results of this study show that tomato lipophilic and hydrophilic tomato extracts exert specific in vitro antioxidant properties in the $\mathrm{DPPH}^{\bullet}$ and $\mathrm{ABTS}^{\bullet+}$ assays. The average yield of the lipophilic fraction obtained via SCE- $\mathrm{CO}_{2}$ extraction was $800 \mathrm{mg}$ from $100 \mathrm{~g}$ of the freeze-dried tomato matrix, with the activity of $251 \pm 3.4 \mu \mathrm{mol} \mathrm{TE} / \mathrm{g}$ extract as measured in the $\mathrm{ABTS}^{\bullet+}$ assay. After extraction, $\mathrm{DPPH}^{\bullet}$-RSA SCE- $\mathrm{CO}_{2}$ sample values were 7 to $12 \%$ higher. There was a strong positive correlation $(\mathrm{R}=0.84)$ between the total content of polyphenolics and the DPPH ${ }^{\bullet}-\mathrm{RSA}^{\circ}$ the tomato samples. The $\mathrm{SC}-\mathrm{CO}_{2}$ extraction parameters could be modified to increase the concentration of the cis-lycopene isomers in the final product (oleoresin) by improving product functionality. The extract of lycopene-rich cis-isomer $(62 \%)$ decreases the viability of glioblastoma cells. The extract of isomerized lycopene decreases the viability of rat glioblastoma C6 cells by $42 \%$. The concentrated extracts with cis-isomers of lycopene could be applied as pharmacological agents with anti-proliferative activities.

The use of bioactive compounds in different commercial sectors, such as the pharmaceutical, food, and chemical industries, makes it very important to extract them or use technological processes that could not only increase the concentrations of the bioactive compounds in the final product but also improve product functionality.

Author Contributions: Conceptualization, D.U., Č.B., R.B., L.R., S.T., J.V. and P.V.; writing-original draft preparation, D.U., C.B., R.B., J.V. and P.V.; writing-review and editing, D.U., J.V., R.B. and P.V.; visualization, D.U., J.V. and L.R.; supervision, P.V.; project administration, D.U. and P.V.; funding acquisition, Č.B. and P.V. All authors have read and agreed to the published version of the manuscript. 
Funding: This study was financed by the Lithuanian Research Centre for Agriculture and Forestry and attributed to the long-term research program, "Horticulture: agrobiological foundations and technologies".

Institutional Review Board Statement: Not applicable.

Informed Consent Statement: Not applicable.

Acknowledgments: The authors are grateful to Audrius Radzevičius for the plant materials.

Conflicts of Interest: The authors declare no conflict of interest.

\section{References}

1. Veiga, M.; Costa, E.M.; Silva, S.; Pintado, M. Impact of plant extracts upon human health: A review. Crit. Rev. Food Sci. Nutr. 2020, 60, 873-886. [CrossRef]

2. Morand, C.; Tomás-Barberán, F.A. Contribution of plant food bioactives in promoting health effects of plant foods: Why look at interindividual variability? Eur. J. Nutr. 2019, 58, 13-19. [CrossRef] [PubMed]

3. Cömert, E.D.; Mogol, B.A.; Gökmen, V. Relationship between color and antioxidant capacity of fruits and vegetables. Curr. Res. Food Sci. 2020, 2, 1-10. [CrossRef]

4. Granato, D.; Barba, F.J.; Bursać Kovačević, D.; Lorenzo, J.M.; Cruz, A.G.; Putnik, P. Functional foods: Product development, technological trends, efficacy testing, and safety. Annu. Rev. Food Sci. Technol. 2020, 11, 93-118. [CrossRef] [PubMed]

5. Lourenço, S.C.; Moldão-Martins, M.; Alves, V.D. Antioxidants of natural plant origins: From sources to food industry applications. Molecules 2019, 24, 4132. [CrossRef]

6. Arathi, B.P.; Raghavendra-Rao Sowmya, P.; Kuriakose, G.C.; Shilpa, S.; Shwetha, H.J.; Kumar, S.; Raju, M.; Baskaran, V.; Lakshminarayana, R. Fractionation and characterization of lycopene-oxidation products by LC-MS/MS (ESI)+: Elucidation of the chemopreventative potency of oxidized lycopene in breast-cancer cell lines. J. Agric. Food Chem. 2018, 66, 11362-11371. [CrossRef] [PubMed]

7. Raiola, A.; Rigano, M.M.; Calafiore, R.; Frusciante, L.; Barone, A. Enhancing the health-promoting effects of tomato fruit for biofortified food. Mediat. Inflamm. 2014, 2014, 139873. [CrossRef] [PubMed]

8. Tohge, T.; Fernie, A.R. Metabolomics-inspired insight into developmental, environmental and genetic aspects of tomato fruit chemical composition and quality. Plant Cell Physiol. 2015, 56, 1681-1696. [CrossRef]

9. Martí, R.; Roselló, S.; Cebolla-Cornejo, J. Tomato as a source of carotenoids and polyphenols targeted to cancer prevention. Cancers 2016, 8, 58. [CrossRef]

10. Palmero, P.; Panozzo, A.; Simatupang, D.; Hendrickx, M.; Van Loey, A. Lycopene and $\beta$-carotene transfer to oil and micellar phases during in vitro digestion of tomato and red carrot based-fractions. Food Res. Int. 2014, 64, 831-838. [CrossRef]

11. Rao, A.V.; Rao, L.G. Carotenoids and human health. Pharmacol. Res. 2007, 55, 207-216. [CrossRef]

12. Bramley, P.M. Is lycopene beneficial to human health? Phytochemistry 2000, 54, 233-236. [CrossRef]

13. Lambelet, P.; Richelle, M.; Bortlik, K.; Franceschi, F.; Giori, A.M. Improving the stability of lycopene Z-isomers in isomerised tomato extracts. Food Chem. 2009, 112, 156-161. [CrossRef]

14. Zhang, L.; Zhang, H.; Ndeurumi, K.H.; Parkin, K.L.; Venuste, M. Thermally-induced geometrical isomerisation of lycopene and its potential influence on functional activity. Food Chem. 2012, 132, 2112-2117. [CrossRef]

15. Liu, D.; Shi, J.; Ibarra, A.C.; Kakuda, Y.; Xue, S.J. The scavenging capacity and synergistic effects of lycopene, vitamin E, vitamin $\mathrm{C}$, and $\beta$-carotene mixtures on the DPPH free radical. LWT-Food Sci. Technol. 2008, 41, 1344-1349. [CrossRef]

16. Stahal, W.; Sies, H. Uptake of lycopene and its geometrical isomers is greater from heat-processed than from unprocessed tomato juice in humans. J. Nutr. 1992, 122, 2161-2166. [CrossRef]

17. Ross, A.B.; Vuong, L.T.; Ruckle, J.; Synal, H.A.; Schulze-König, T.; Wertz, K.; Rümbeli, R.; Liberman, G.R.; Skipper, P.L.; Tannenbaum, S.R.; et al. Lycopene bioavailability and metabolism in humans: An accelerator mass spectrometry study. Am. J. Clin. Nutr. 2011, 93, 1263-1273. [CrossRef] [PubMed]

18. Urbonaviciene, D.; Viskelis, P. The cis-lycopene isomers composition in supercritical $\mathrm{CO}_{2}$ extracted tomato by-products. $L W T$-Food Sci. Technol. 2017, 85, 517-523. [CrossRef]

19. Urbonaviciene, D.; Bobinaitè, R.; Trumbeckaitè, S.; Raudonė, L.; Janulis, V.; Bobinas, Č.; Viškelis, P. Agro-industrial tomato by-products and extraction of functional food ingredients. Zemdirb. Agric. 2018, 105, 63-70. [CrossRef]

20. Stahl, W.; Sies, H. Antioxidant activity of carotenoids. Mol. Asp. Med. 2003, 24, 345-351. [CrossRef]

21. Müller, L.; Goupy, P.; Fröhlich, K.; Dangles, O.; Caris-Veyrat, C.; Böhm, V. Comparative study on antioxidant activity of lycopene (Z)-isomers in different assays. J. Agric. Food Chem. 2011, 59, 4504-4511. [CrossRef]

22. Hadad, N.; Levy, R. The synergistic anti-inflammatory effects of lycopene, lutein, $\beta$-carotene, and carnosic acid combinations via redox-based inhibition of NF-kB signaling. Free Radic. Biol. Med. 2012, 53, 1381-1391. [CrossRef] [PubMed]

23. Milde, J.; Elstner, E.F.; Graßmann, J. Synergistic effects of phenolics and carotenoids on human low-density lipoprotein oxidation. Mol. Nutr. Food Res. 2007, 51, 956-961. [CrossRef] [PubMed]

24. Scalzo, J.; Politi, A.; Pellegrini, N.; Mezzetti, B.; Battino, M. Plant genotype affects total antioxidant capacity and phenolic contents in fruit. Nutrition 2005, 21, 207-213. [CrossRef] 
25. Crozier, A.; Jaganath, I.B.; Clifford, M.N. Dietary phenolics: Chemistry, bioavailability and effects on health. Nat. Prod. Rep. 2009, 26, 1001-1043. [CrossRef]

26. Bhatta, S.; Stevanovic Janezic, T.; Ratti, C. Freeze-Drying of Plant-Based Foods. Foods 2020, 9, 87. [CrossRef] [PubMed]

27. Rizzo, V.; Clifford, M.N.; Brown, J.E.; Siracusa, L.; Muratore, G. Effects of processing on the polyphenol and phenolic acid content and antioxidant capacity of semi-dried cherry tomatoes (Lycopersicon esculentum M.). J. Sci. Food Agric. 2016, 96, 2040-2046. [CrossRef] [PubMed]

28. Abascal, K.; Ganora, L.; Yarnell, E. The effect of freeze-drying and its implications for botanical medicine: A review. Phytother. Res. 2005, 19, 655-660. [CrossRef] [PubMed]

29. BBC Research. The Global Market for Carotenoids; Report FOD025F; März, U., Ed.; 2018. Available online: https:/ /www.bccresearch. $\mathrm{com} /$ market-research/food-and-beverage/the-global-market-for-carotenoids.html (accessed on 20 January 2021).

30. Tamkutè, L.; Pukalskas, A.; Syrpas, M.; Urbonavičienė, D.; Viškelis, P.; Venskutonis, P.R. Fractionation of cranberry pomace lipids by supercritical carbon dioxide extraction and on-line separation of extracts at low temperatures. J. Supercrit. Fluids 2020, 163, 104884.

31. Bobinaite, R.; Viškelis, P.; Venskutonis, P.R. Variation of total phenolics, anthocyanins, ellagic acid and radical scavenging capacity in various raspberry (Rubus spp.) cultivars. Food Chem. 2012, 132, 1495-1501.

32. Re, R.; Pellegrini, N.; Proteggente, A.; Pannala, A.; Yang, M.; Rice-Evans, C. Antioxidant activity applying an improved ABTS radical cation decolorization assay. Free Radic. Biol. Med. 1999, 26, 1231-1237. [CrossRef]

33. Brand-Williams, W.; Cuvelier, M.E.; Berset, C. Use of a free radical method to evaluate antioxidant activity. Lebensm. Wiss. Technol. 1995, 28, 25-30. [CrossRef]

34. Hakala, S.H.; Heinonen, I.M. Chromatographic purification of natural lycopene. J. Agric. Food Chem. 1994, 42, 1314-1316. [CrossRef]

35. Topal, U.; Sasaki, M.; Goto, M.; Hayakawa, K. Extraction of lycopene from tomato skin with supercritical carbon dioxide: Effect of operating conditions and solubility analysis. J. Agric. Food Chem. 2006, 54, 5604-5610. [CrossRef] [PubMed]

36. Bobinaitè, R.; Kraujalis, P.; Tamkutè, L.; Urbonavičienè, D.; Viškelis, P.; Venskutonis, P.R. Recovery of bioactive substances from rowanberry pomace by consecutive extraction with supercritical carbon dioxide and pressurized solvents. J. Ind. Eng. Chem. 2020, $85,152-160$.

37. Grunovaitè, L.; Pukalskienè, M.; Pukalskas, A.; Venskutonis, P.R. Fractionation of black chokeberry pomace into functional ingredients using high pressure extraction methods and evaluation of their antioxidant capacity and chemical composition. $J$. Funct. Foods 2016, 24, 85-96. [CrossRef]

38. Szabo, K.; Diaconeasa, Z.; Cătoi, A.F.; Vodnar, D.C. Screening of ten tomato varieties processing waste for bioactive components and their related antioxidant and antimicrobial activitie. Antioxidants 2019, 8, 292. [CrossRef] [PubMed]

39. Viskelis, P.; Radzevicius, A.; Urbonaviciene, D.; Viskelis, J.; Karkleliene, R.; Bobinas, C. Biochemical parameters in tomato fruits from different cultivars as functional foods for agricultural, industrial, and pharmaceutical uses. In Plants for the Future; El-Shemy, H., Ed.; InTech Open: Rijeka, Croatia, 2015; Volume 10, p. 60873.

40. Shao, D.; Atungulu, G.G.; Pan, Z.; Yue, T.; Zhang, A.; Li, X. Study of optimal extraction conditions for achieving high yield and antioxidant activity of tomato seed oil. J. Food Sci. 2012, 77, E202-E208. [CrossRef] [PubMed]

41. Lim, S.K.; Llaguno, S.R.; McKay, R.M.; Parada, L.F. Glioblastoma multiforme: A perspective on recent findings in human cancer and mouse models. BMB Rep. 2011, 44, 158-164. [CrossRef]

42. Wang, J.; Yi, J. Cancer cell killing via ROS: To increase or decrease, that is the question. Cancer Biol. Ther. 2008, 7, 1875-1884. [CrossRef]

43. Linnewiel-Hermoni, K.; Khanin, M.; Danilenko, M.; Zango, G.; Amosi, Y.; Levy, J.; Sharoni, Y. The anti-cancer effects of carotenoids and other phytonutrients resides in their combined activity. Arch. Biochem. Biophys. 2015, 572, 28-35. [CrossRef] [PubMed]

44. Kumar, S.R.; Hosokawa, M.; Miyashita, K. Fucoxanthin: A marine carotenoid exerting anti-cancer effects by affecting multiple mechanisms. Mar. Drugs 2013, 11, 5130-5147. [CrossRef]

45. Zini, A.; San Gabriel, M.; Libman, J. Lycopene supplementation in vitro can protect human sperm deoxyribonucleic acid from oxidative damage. Fertil. Steril. 2010, 94, 1033-1036. [CrossRef] [PubMed]

46. Seo, J.Y.; Masamune, A.; Shimosegawa, T.; Kim, H. Protective Effect of Lycopene on Oxidative Stress-Induced Cell Death of Pancreatic Acinar Cells. Ann. N. Y. Acad. Sci. 2009, 1171, 570-575. [CrossRef] [PubMed] 